\title{
A New Look at the Geological Structure of the Knurów Hard Coal Deposit in Light of Model Tests
}

Piotr Sosnowski

University of Silesia in Katowice, JSW S.A. KWK Knurów-Szczygłowice, Poland

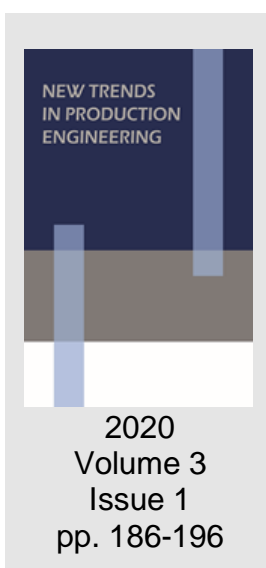

Date of submission to the Editor: 02/2020

Date of acceptance by the Editor: 03/2020

\section{INTRODUCTION}

The purpose of the 3D modeling and production scheduling project at JSW S.A. is to create a three-dimensional model of the deposits being part of JSW. The modeling covers industrial seams, for which mining is planned until 2030. The effect and at the same time the primary goal is to create a powerful database with resources and qualitative parameters of our coals, so that it can be immediately available in practice to the geological services. Finally, said data will be used for automatic preparation of long-term mining schedules with the perspective of mining of seams with the optimum parameters (Sosnowski 2019). The Knurów deposit is located within the administrative boundaries of towns of Gliwice and Knurów, as well as Czerwionka-Leszczyny and Gierałtowice municipalities. The area of the documented deposit is $40.35 \mathrm{~km}^{2}$. The deposit encompassing Upper Carboniferous (Namurian and Westphalian) is composed of coal seams of Orzesze layers (seams of 300 group, Westphalian B), Ruda Śląska layers (seams of 400 group, Westphalian A), saddle layers (seams of 500 group, Namurian B-C) and Poręba layers (seams of 600 group, Namurian A). The whole is interbedded by packages of sedimentary rocks such as claystones, mudstones, sandstones and conglomerates. The deposit is characterized by intensive fold and fault tectonics related to the proximity of presence of two large dislocation zones of regional significance. These are Orłowa-Boguszowice thrust fault and Michałkowice-Rybnik thrust fault running on the western verges of the mining area. The primary fault zones include four ones with the greatest influence on the morphology of the deposit. These are: Gieraltowice fault zone with the width of ca. 300 meters with the total amplitude of throws being 40 meters; central fault zone with the throw ranging from 12 to 22 meters; Beksza fault zone with throws ranging from 25 and 40 meters; and Ornontowice fault zone with the vertical reach of up to 18 metres. Furthermore, there are a range of smaller faults located within the whole deposit area. When moving from the northern boundary with the Sośnica mine southwards, the deposit is intersected by a fold zone called "Knurów anticline", composed of two 
saddles and two troughs, which is continued in the "Szczygłowice" and "Dębieńsko" deposits (Fig. 1).

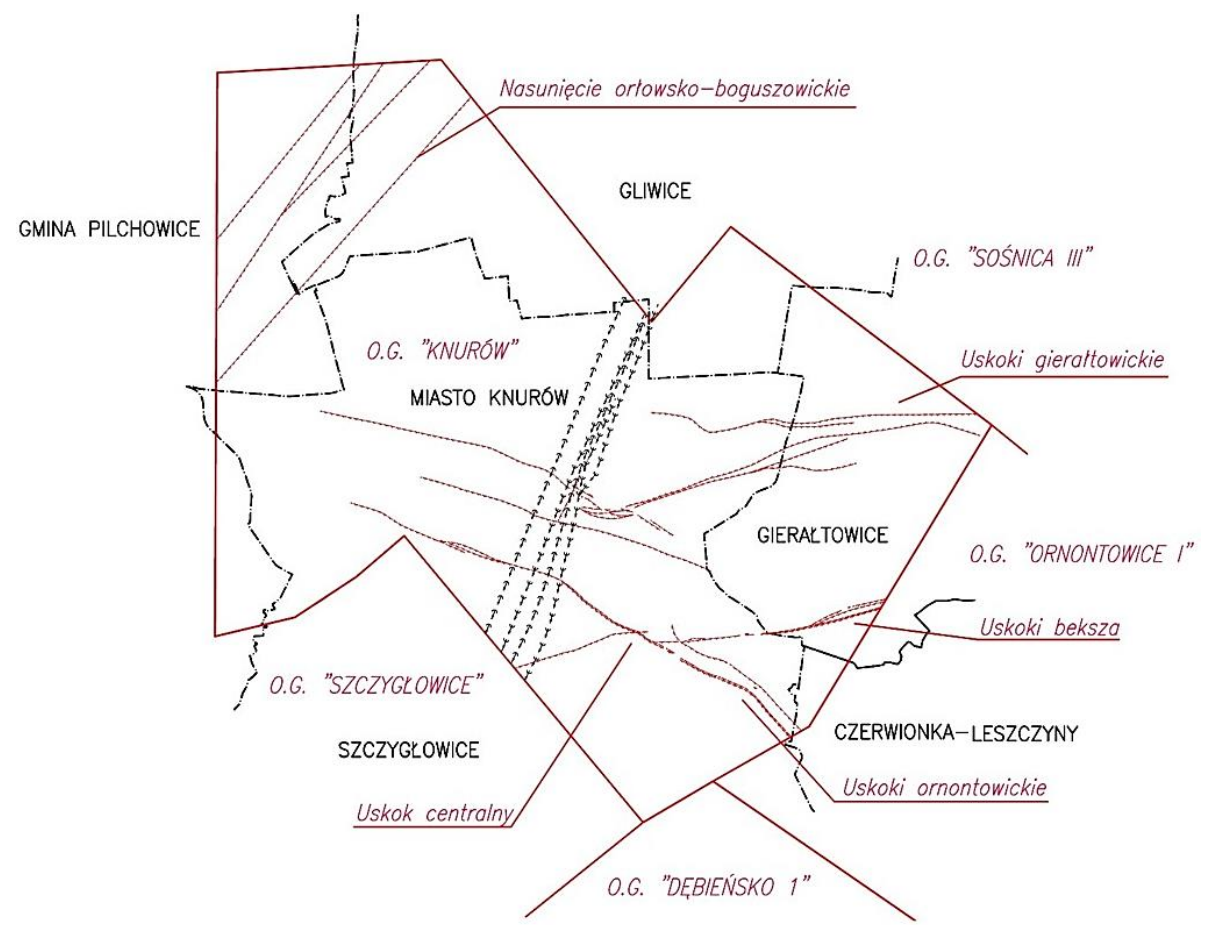

Fig. 1 Layout plan of the Knurów mining area with the administrative division, marked primary fault zones and the fold zone

The northern part of the deposit (decommissioned) is dominated by a series of thrust faults and thrust slices (EC KPG 2012), while the part south of the "Knurów anticline" is a monocline dipping SE at an average angle of $15^{\circ}$. The thicknesses of the seams that are mined and intended for further use range from $1.50 \mathrm{~m}$ to over $6 \mathrm{~m}$. The deposit was explored and documented to the level of $1050 \mathrm{~m}$. The prevailing types of coal according to PN-82/G-97002 are type 34.2 semi-soft coking coal and 35.1 hard coking coal (PN-82/G-97002). These coal types are characterized by very good qualitative parameters that enable their use both in energy generation and in cokemaking (Diez et al., 2002).

The purpose of the publication is to demonstrate the possibilities of computer software used for 3D modeling when recognizing the geological structure of not only newly recognized deposits, but also those already exploited.

\section{THREE-DIMENSIONAL DEPOSIT MODELING}

The key role in the exploration of the geological structure over the past years has been played by the Polish Geological Institute - National Research Institute (PIG-PIB). Pursuant to the applicable Geological and Mining Law (Journal of Laws of 2019, item 868), it is PIG-PIB that is responsible for exploration of the underground geological structure of Poland, thereby for parametric modeling of shallow geological structures in Poland. The standpoint of PIG-PIB is clear: 3D geological modeling, coordination and interpretation of the generated 3D models should become a statutory task of the geological service (Jelonek et al., 2017). A significant role in underground mining of coal-bearing formations 
is played both by underground mapping and by assessment of natural hazards and those caused by coal mining. Recently, the Polish hard coal mining industry has seen the application of digital technologies of map preparation and subsurface data management, which are related to GIS technologies. However, fully three-dimensional geological modeling based on numerical methods has been employed only sporadically in the industrial practice, unlike prospecting and mining of crude oil and gas - this is a common practice in these areas (Stano et al., 2014).

The primary task of geological cartography and of modeling is the possibly most faithful presentation of an image of the geological structure of a given tested area. At the subsequent stages, cartographic modeling through inclusion of numerical models of deposits enables rational management of natural resources in accordance with the guidelines of the applicable Geological and Mining Law. In addition, the possibility for an operating mine to manage data effectively in a geological and a numerical model constitutes the basis for an effective use of the resources of the mineral (e.g. hard coal) deposit, for optimization of mining costs and for mining prediction (Jelonek et al., 2017).

\section{MODEL TESTS}

The broadly understood term of model tests refers above all to experimental tests of a given object to specify its fitness for the intended purpose. Modeling is an inevitable part of numerous scientific disciplines (Cartwright, 1983) and in this case it should be understood as the use of science for industrial achievements. In the context of a 3D model of a deposit, one should use the attribute geological with model tests because apart from the reasonability of performance of tests that verify the creation of a model and its fitness in processes related to production scheduling and mine operation management also the degree of geological exploration of a deposit is re-verified or initially verified, which enables an introduction of necessary modifications for the purpose of its correct geometrization. Therefore, it is correct to regard a geological model in the context of an experimental model as a system of assumptions and correlations between objects.

The main inconvenience in modeling is the too low volume of data from boreholes. In the case of certain plots it is possible to take advantage of drift logs that are converted by algorithms into virtual geological boreholes. However, it must be borne in mind that the number of boreholes does not depend on the 3D model author but on the project owner that explores the deposit. In certain cases, the generated floor surface may involve a too big error. In line with the increase in information volume as a result of better deposit exploration, the model can be updated on an ongoing basis (Probierz et al., 2017).

In the case of the Knurów (Fig. 2), deposit, the detailed analysis covered the main fault zones in poorly explored areas, the running of minor accessory faults, the development of the Knurów anticline, and the variability of relations between the adjacent seams in terms of splitting and merging. 


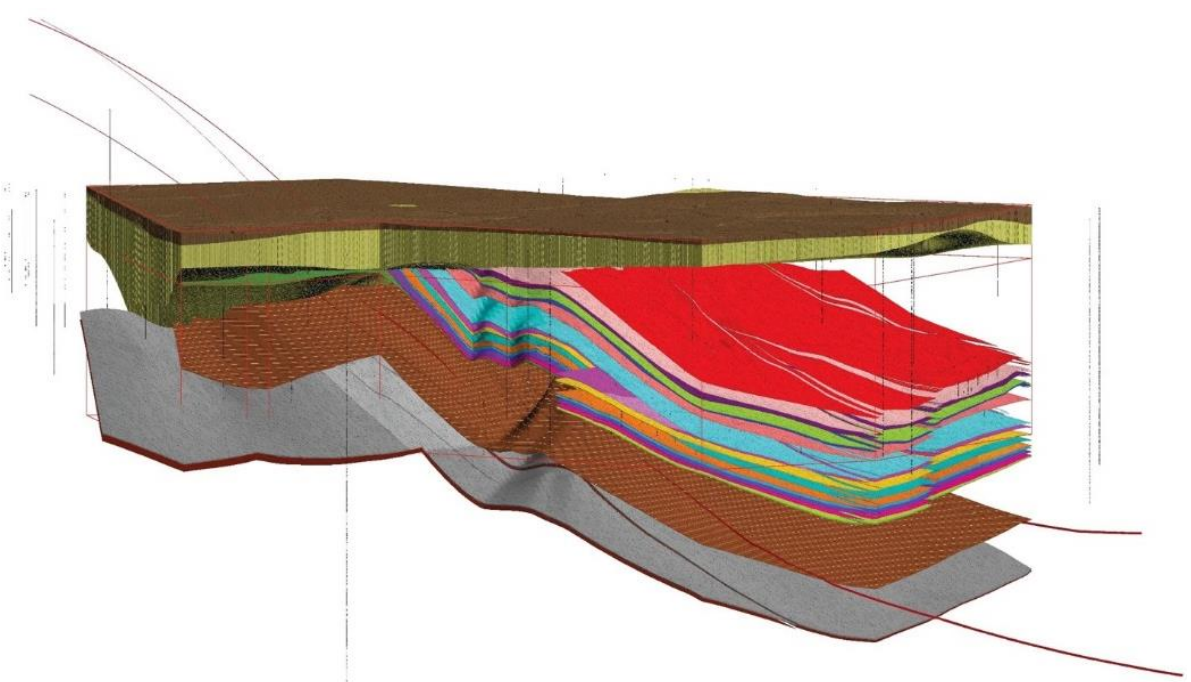

Fig. 2 Rendering of a three-dimensional model of the Knurów deposit

\section{DEPOSIT OVERBURDEN}

A relatively low number of boreholes from the surface were made for the original exploration of the morphology and deposition of the Carboniferous floor and ceiling. However, this enables a relatively correct rendering of the surface but with certain reservations. An accurate view of the development of the overburden formations was provided by borehole exploration performed from mine workings. These data were used for creating a map of the Carboniferous ceiling being a component of the Knurów deposit documentation, which upon digitization in AutoCAD Civil 3D by Autodesk served for rendering the overburden surface in the 3D model of the deposit (Fig. 3).

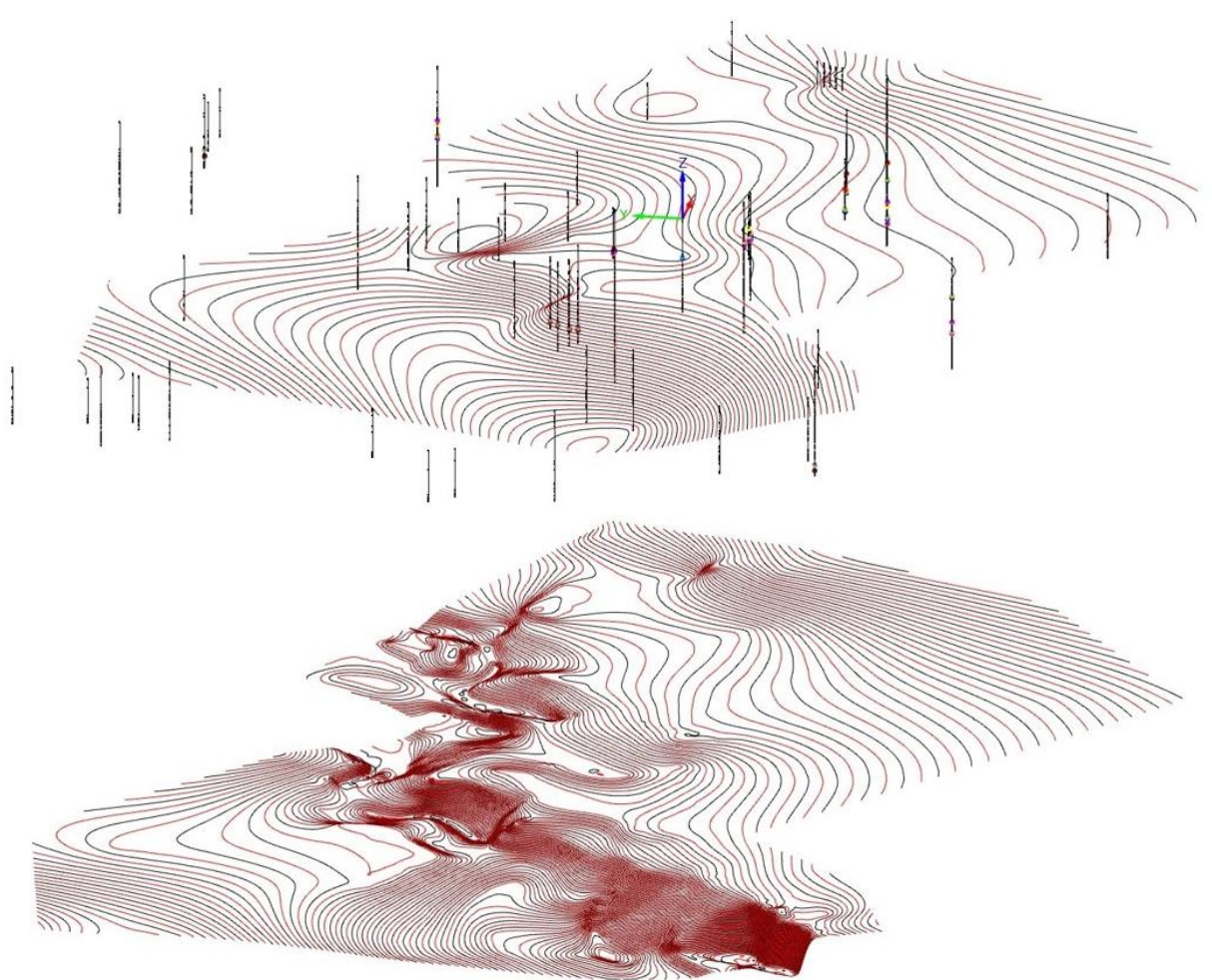

Fig. 3 Carboniferous ceiling map imported and rendered in Datamine Minescape. Overburden projection generated based on borehole data and with the use of data acquired from the digital map generated in AutoCAD by Autodesk 
Upon uploading, the isolines created using the 3D polyline were converted into the grid surface, which fulfils the role of a transgressive surface defining the outcrops of the seams being modeled.

\section{CARBONIFEROUS AND DEVELOPMENT OF SEAMS}

The geological stage of Carboniferous in the Knurów deposit is composed of Orzesze layers (seams of 300 group), Ruda Śląska layers (seams of 400 group), saddle layers (seams of 500 group) and Poręba layers (seams of 600 group). The following seams were subject to modeling: 355, 359, 361, 401/1, 401/2, 403/1, 404/5, 405/1, 405/3, 406/2, 407/1, 407/2, 407/3, 408/1, 408/2, 408/3, 413/1, 416, 504, 507 and their merged portions: 4051/1 + unspecified layer, 405/1+405/3, 4071/1+407/2, 407/2+407/3, 408/3 + unspecified layer,

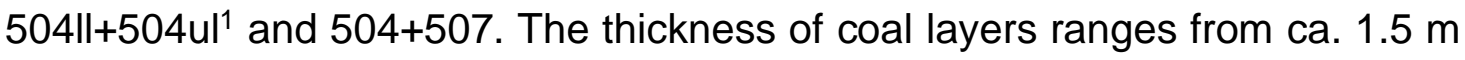
to over $6 \mathrm{~m}$. The lithology in the majority of cases is invariable and encompasses minor inserts of several to more than ten centimeter partings. The high variability of interbedding of seams with gangue, in turn, is common in the case of Orzesze layers. In these seams, the share of partings may reach up to several dozen per cent by volume.

The choice of these seams resulted from the optimum, in terms of market demand, quality parameters of the coals, the possibility to open them out, their thickness and the rational deposit management. Certain seams are used up to a considerable extent, which, in the context of creation of a three-dimensional model of the deposit, translates into very good exploration of the geological situation (the course of disruptions, the deposition of seams and wall rocks). This enables correct modeling of surfaces of less explored seams by assigning trends of layer deposition, covering the whole deposit.

The logic of modeling with the use of DATAMINE Minescape software consists in assigning a trend to one layer (most often this is the first highest lying one) and transferring it to lower lying formations. It is also possible to model seams separately or divided by geological stages without the use of a trend but observing the stratigraphic succession. Due to the monoclinal nature of the deposit and to the various degree of Knurów anticline erosion, additional data had to be used for modeling the fold axis and modeling with a trend had to be abandoned. Due to the various degrees of seam pinch out in the folding zone, these data had to be implemented separately for each seam.

\section{DISCONTINUOUS DISLOCATION ZONES Choice of fault modeling manner}

Four main fault zones were documented within the Knurów deposit boundaries. These are (from the west): Ornontowice fault zone composed of several faults with the throws ranging from ca. 2-3 meters to ca. 18 meters. It was explored at all mining levels of the mine with the use of crosscuts and exploratory

\footnotetext{
1504 lower layer + 504 upper layer. The terms lower and upper layer in the model were assigned accordingly to all seams in the splitting zones although they are not documented.
} 
boreholes. Subsequently the Beksza fault zone occurs, which is composed of the main fault with the throw of up to $25 \mathrm{~m}$ and several to more than ten minor accessory faults. Both these fault zones form a central fault zone in the northern direction with the throws of $\sim 2-20 \mathrm{~m}$ along with numerous accompanying faults. These disruptions were explored with the use of carrying gangways and opening-out headings. The last main zone is the Gierałtowice graben built of a variable number of irregular faults in the deposit transect, with the throws ranging from several to several dozen meters. All the enumerated fault zones are continued in the adjacent deposits, i.e. Ornontowice deposit belonging to KWK Budryk and Sośnica deposit from KWK Sośnica.

In the first run of the model creation, only main faults were used jointly for all seams. The level of $850 \mathrm{~m}$ (-605 m ASL) was used as the reference level. Another considered manner is to introduce faults for a single seam and to project them to the lower lying seams or to model disruptions separately for each seam. Due to the complexity of the development and the high variability of the running in the transect, this solution was abandoned at the present stage. The faults in the considered deposit tend to "flatten out" in line with depth and to increase or decrease the throw value, which is impossible to model for single dislocation structures.

Finally, the faults were modeled separately for each geological stage encompassing the Carboniferous coal-bearing series. Nevertheless, the decision was made with the proximity of seams rather than the stratigraphic terminology in mind. Thus, the stage of Orzesze layers covered only seam 355 with a separate system of faults. The stage of Ruda Śląska layers 1 begins with seam 359 and ends with seam 403/1, the stage of Ruda Śląska layers 2 is located between seam $404 / 5$ and $408 / 3$, seams $413 / 1$ and 416 are modeled in the stage of Ruda Śląska layers 3 , while seams of 500 group encompass a stage of saddle layers in an analogy to the remaining stages with its own system of faults. The disruptions were modeled based on the best explored seam from each of the stages, and after projecting them to the appropriate surface their parameters were modeled such that the actual condition could be reflected as well as possible.

\section{Analysis of development of fault zones}

The primary information about the development and strikes of faults is the geological documentation of the deposit extended by underground surveys in mine workings. The mapping of faults in two dimensions on maps and geological transects basically causes no limitations as to the data interpretation. The 3D model of a deposit imposes certain restrictions on the contractor, forcing it to adjust the strikes and throws to the lithology and elevation information at hand in the explored areas of the deposit. When assuming a rock massif as a rigid body, it is not possible to form faults randomly without taking into account the determined levels in the modeled surfaces. Making a map of isolines of the floor or ceiling of a given seam and comparing the running of the fault planes with the documented condition permits corrective measures by steering 
the strike azimuth or the throw to adjust them appropriately. Correct modeling of faults is of great importance when exporting the generated bodies of seams to DESWIK software. The accuracy of the model will increase the effectiveness of design of new workings, taking into account difficulties related to work performance in geological disruption zones.

An example here is the crosscut at the level of $1050 \mathrm{~m}$, which was designed in parallel to the running of the zone of Ornontowice faults (Fig. 4).

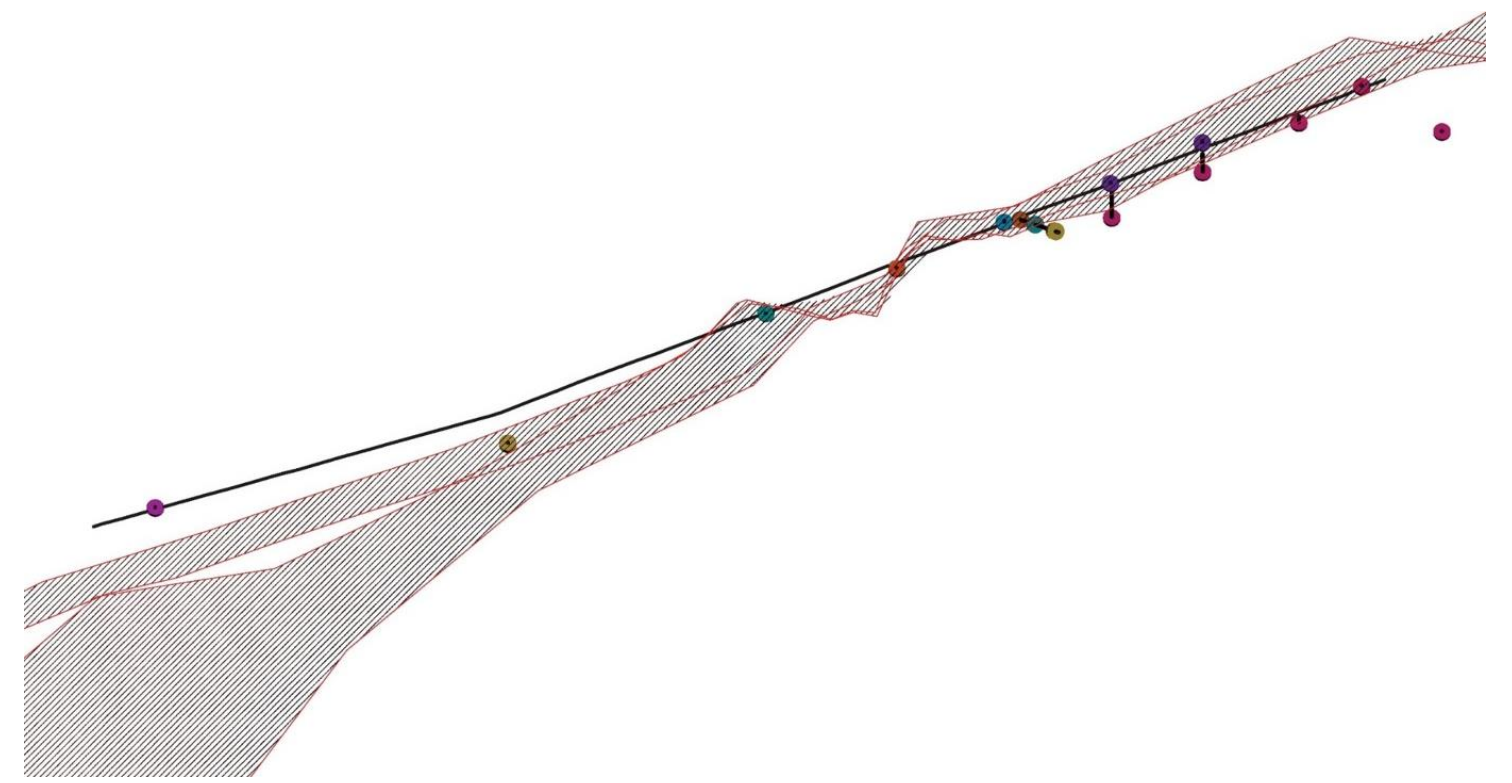

Fig. 4 Plan view of the axis of the crosscut run in the fault zone. The fault surface as well as identified seams in drift boreholes and profiles were rendered

As a result of poor exploration of the relevant area of the deposit, a fault with the throw of ca. $10 \mathrm{~m}$, being one of the faults from the described zone, was cut during mining works. The disruption occurred in the working face for ca. 200 meters. This showed the complexity of the development and running as well as the unpredictability of so big dislocation zones. Due the lack of data on the development of the fault zone in the relevant area of the deposit, the model was unable to predict the situation that occurred. The matter was further complicated by the quantity of the seams cut by the working, where most of them were modeled but similar thicknesses and lithologies impeded their identification. An attempt was made to identify them in the model and adjust them to the running of the disruption (Fig. 5).

After several attempts a satisfactory effect was achieved. Therefore, it becomes impossible to model information confirmable in $100 \%$ without the use of data. A specific fact can be assumed hypothetically. When modeling poorly explored regions of the deposit, in particular those with strong tectonic disruptions, the work results must be received with a certain degree of probability. Data must be gradually acquired and implemented to the model and subsequently attempts at interpretation must be made to achieve the intended result. 


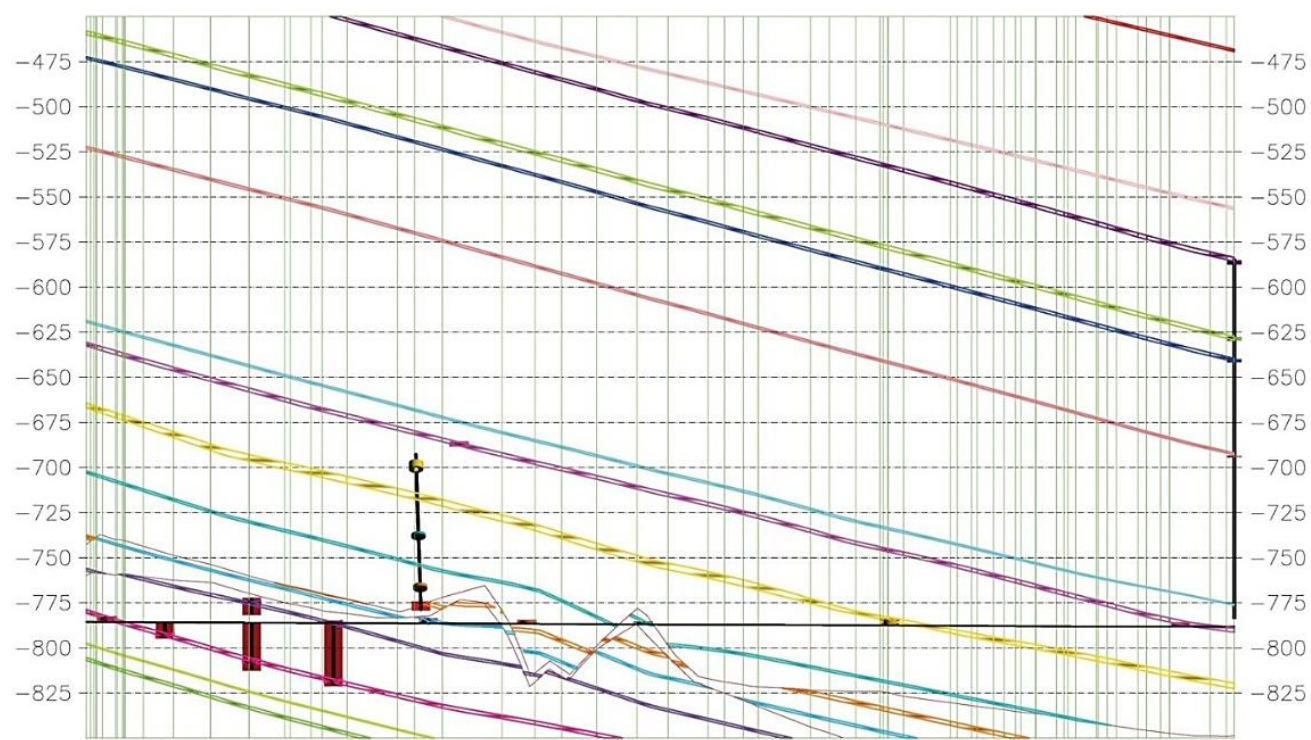

Fig. 5 Geological transect generated along the crosscut made in the fault zone. The axis of the working, the exploratory boreholes made, the running of the fault zone and the modeled seams are marked in the transect

\section{FOLD ZONES}

\section{Running and development of Knurów anticline}

The Knurów anticline is a part of a large fold zone explored in other mines of the Upper Silesian Coal Basin (Fig. 6), among others in KWK Makoszowy and KWK Sośnica, and while intersecting the area of Knurów deposit in the NNE-SSW direction it is continued in Szczygłowice and Dębieńsko deposits.

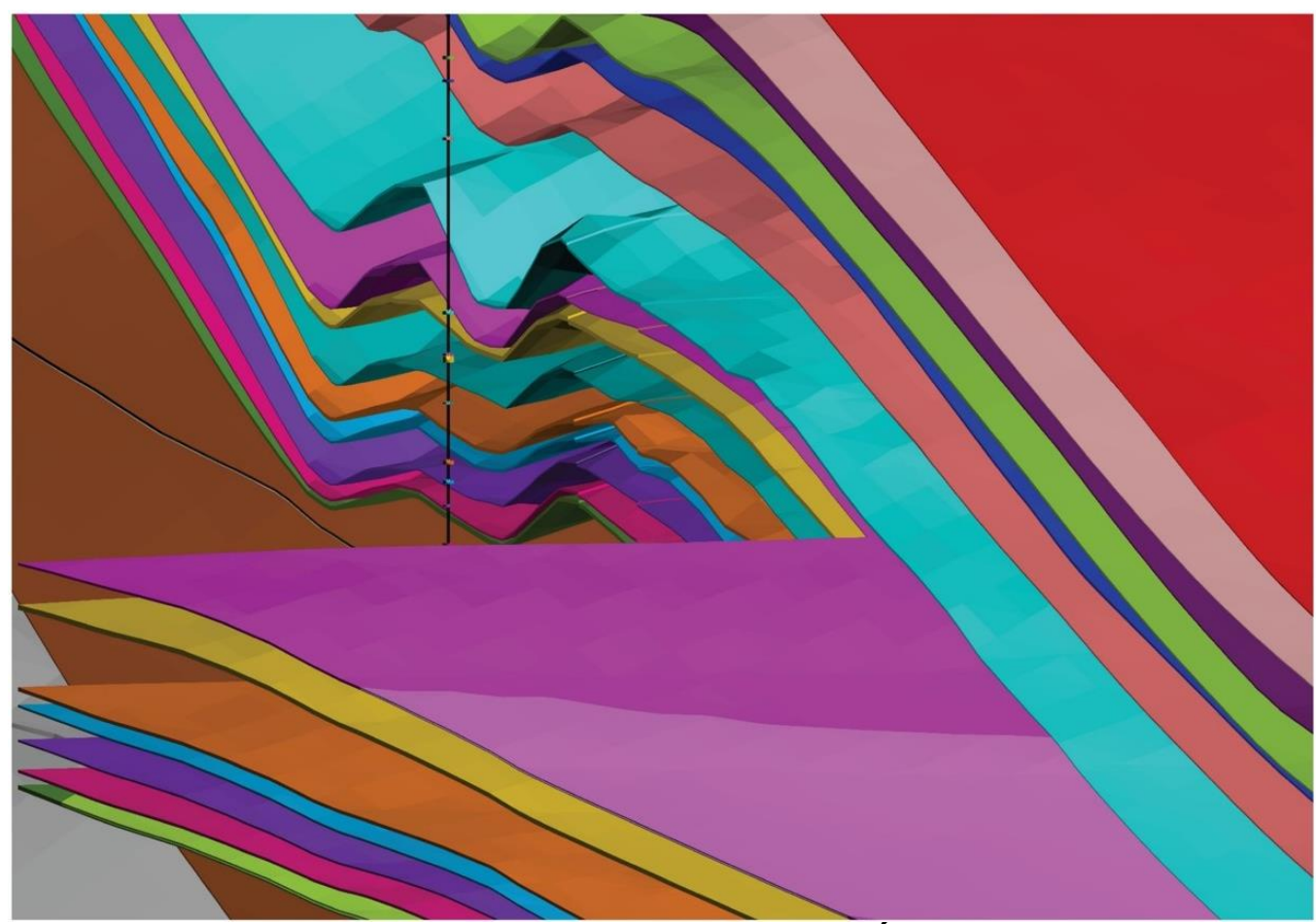

Fig. 6 Zoomed in modeled fold zone in Ruda Śląska layers seen from the Szczygłowice deposit side

The structure is generally composed of two synclines and two anticlines with various intensity of degree of development. The fold amplitude increases in line 
with the depth of deposition, which entails an increase in inclination of rock layers on the limbs, reaching even over $60^{\circ}$. The zone was explored mainly by mining works in crosscuts. The mining in the disruption region was performed in the 1920s-1940s and was documented to a very small degree. In particular, there are no elevation data (elevations of working floors) which could be used for easy modeling of the seam surfaces.

\section{FOLD MODELING}

Due to the insufficient volume of elevation data for "folding" the modeled seam surfaces, so-called surveying data were used, applying for this purpose level isolines of seams from the deposit's geological documentation. Based on the acquired data, fold axes were created artificially, adjusting their running to the generally adopted trend. This process enabled an elevation-based interpolation of geological data coming from logging of workings and the assignment of a relevant elevation to them, thereby supporting the modeling of the fold's limbs and supplementing the model with lithologic data. The disruption's running and development can be traced with the use of intersection transects made in parallel to each other along the running of the folding.

The described tectonic disruption is visible best in the modeled seams of the saddle layers, i.e. 504 and 507. Given that there is no mining in this region and solely relying on exploration based on boreholes and having a low volume of data from the adjacent deposit, the data from the 3D model should be incorporated in the future to update the deposit's geological documentation. The running of level isolines and the interpretation of the axes of folds are in conflict with the preset modeling trend and several boreholes. An optimum solution is to add or relocate a trough axis and to preset additional data in order to overbend the seam appropriately.

\section{RELATION BETWEEN MODEL AND DEPOSIT EXPLORATION Impact of deposit exploration on model correctness}

The accuracy of deposit exploration is affected by the data volume and quality. The familiarity with the geological structure of the modeled deposit imposes the direction of the design preparation to a strictly determined form. The large volume of borehole data, loggings, and elevation data imposes an accurate analysis of fault structures and adjustment of their throws and strikes in the regions characterized by a differing degree of exploration. Adjustment of a given fault is an impediment in a situation when its parameters change in the transect. In such a case a compromise has to be found between the model accuracy and the requirements set for the model. In the case of different disruptions, such as foldings, it is important to have correct elevation data and the running of the axes. If there are none or only few, elevation and lithologic data must be entered artificially in accordance with the documentation at hand.

Paradoxically, a large volume of data entered to the model makes its creation more complicated. Despite the broad resource of qualitative and quantitative 
information about the deposit, its shape and correct surface rendering may deviate from the actual condition and aesthetic standards at single spots.

\section{Impact of model on correctness of deposit exploration}

If there are no rich surveying and geological information resources available for the modeled deposit as a result of poor exploration or if certain regions are poorly documented, then thanks to $3 \mathrm{D}$ modeling it is possible to verify the geological interpretation prepared by the documentation author. The application of software algorithms to transfer the trend of layer deposition to the underlying formations makes it possible to create, with a high probability, correct geological transects observing the distances between seams and the correct inclinations. The design of faults in model tests provides greater possibilities of their correct interpretation due to the almost unlimited control of the throw values. Such an operation permits modification of the modeled seam surfaces to adjust them correctly. In the case of too low or high throw values in the output graphic files unnatural overbendings appear in fault regions. An appropriate interpretation and modeling of fault zones enables effective design of future mine workings in the deposit being explored.

In the case of fold zones, if there is no information about their presence and possible running, the only possibility to acquire information is to trace the morphologic development of the adjacent deposits. On compiling a presumable running of the folding, the surveying data specifying the depths of the floor of the modeled layer must be fed to the model, thereby assigning the trend of the designed fold.

\section{CONCLUSION}

A tool being 3D modeling computer software provides a wide spectrum of possibilities in the field of deposit exploration and of working design in already explored deposits. Thanks to the application of modern IT tools using appropriate computer algorithms, a documenting geologist enjoys time savings due to the transfer of the cartographic analysis of the documented deposit to the virtual reality. A spatial rendering of the deposit shows it in a different light and helps develop the spatial visualization ability. In the future, 3D modeling software will be a common and inevitable tool in the geologist's workshop and the generally understood mining industry.

\section{REFERENCES}

Cartwright, N., (1983) How the Laws of Physics Lie. Oxford University Press

EC Katowickie Przedsiębiorstwo Geologiczne Sp. z o. o., (2012) Dodatek nr 2 do dokumentacji geologicznej złoża węgla kamiennego „Knurów” w kategoriach A, B, C1 i C2, Katowice

Jelonek I., Poniewiera M., Jelonek Z., (2017) Modelowanie złóż w oparciu o właściwości petrograficzne kopalin stałych na przykładzie Jastrzębskiej Spółki węglowej S.A., Górnictwo odkrywkowe nr 2/ 
M.A. Diez, R. Alvarez, C. Barriocanal, (2002) Coal for metallurgical coke production: predictions of coke quality and future requirements for cokemaking, International Journal of Coal Geology 50 pp. 389-412

Probierz K., Ignacok D., (2017) Trójwymiarowy model złoża węgla kamiennego z zastosowaniem środowiska CAD na przykładzie SW części GZW, Górnictwo Odkrywkowe $\mathrm{nr} 3$

Stano M., Żaba J., Małolepszy Z., (2014) Trójwymiarowy model geologiczny złoża węgla kamiennego KWK „Knurów-Szczygłowice”, Przegląd Geologiczny, vol. 62 nr 12

Sosnowski P., (2019) Model złoża i harmonogramowanie produkcji w JSW SA, Nowy Górnik nr 13, pp. 7

Act of 9 June 2011 entitled Geological and Mining Law (Journal of Laws of 2019, item 868).

Polish Standard PN-82/G-97002 Hard coal - Types

\begin{abstract}
.
The Knurów hard coal deposit is characterized by rich fold and fault tectonics and diverse morphology of the overburden. The deposit contains a fold zone called Knurów anticline and four complex of faults with the total amplitudes reaching up to several dozen meters. While making a 3D model of the deposit, a range of complications related to the correct interpretation of the running and development of the aforementioned tectonic structures were encountered. Additional data were begun to be introduced during the detailed analysis of the 3D model being made in stages, thereby forcing the software to perform the modeling according to preset assumptions. This process covered such areas of the deposit that were poorly explored or documented to an extent requiring an intervention from a geologist.
\end{abstract}

Keywords: Model research, 3D model of the deposit, fault zones, fold zones 